\title{
Union Democracy and Labour Rights: A Cautionary Tale
}

\author{
Brad Walchuk, York University, Canada
}

The great seem great to us only because we are on our knees - Let us rise!

- motto from French Revolution, 1789 (cited in Draper, 1977: 225)

\begin{abstract}
In recent years, trade unions in Canada have become increasingly reliant on constructing workers' rights as part of the broader rubric of human rights. While the topic of labour rights has become popular in recent academic literature, it remains under explored. An important element of constructing labour rights as human rights is its impact on union democracy and rank-and-file mobilization, though this has yet to be fully explored. Utilizing the case study of the Hospital Employees' Union (HEU) struggle against Bill 29, this paper suggests that a reliance on the construction of labour rights as human rights and the corresponding judicial strategy prevents the development of a from a more radical, grassroots social movement unionism and instead facilitates the proliferation of hierarchical, elite dominated forms trade unionism. It concludes by suggesting that unions must be cautious of the potential downfalls of quelling militant grassroots activism in lieu of a rights-based challenge.
\end{abstract}

\section{KEYWORDS}

Bill 29, Hospital Employees Union (HEU), labour rights, social movement unionism, union democracy

\section{Introduction}

In recent years, trade unions in Canada have become increasingly reliant on constructing the rights of workers, both organized and unorganized, as being part of the broader rubric of human rights. The usage of rights discourse necessitates that the legal system, at both the national and international level, becomes the venue in which organized labour fights its battles. In order to 
undertake these legalistic battles, the labour movement increasingly relies on rights-based documents such as the Canadian Charter of Rights and Freedoms and various International Labour Organization (ILO) conventions, notably No. 87 (Freedom of Association and the Right to Organize) and No. 98 (The Right to Organize and Collective Bargaining).

The labour movement's recent embrace of rights-discourse can be explained by a number of factors, including the fact that neo-liberalism (and its accompanying attack on organized labour) has become the dominant political ideology, the labour movement's social democratic allies have done little to protect and further it, union density has begun to decrease in the past few decades, the language of 'rights speak' has become increasingly salient in popular discourse, and many of organized labour's allies - feminist groups, gay and lesbian rights organizations, Aboriginal groups and ethno-cultural organizations - have successfully used the Charter to gain rights and alter government action (Panitch and Swartz 2003: chs. 4-9; Hein 2001: 214-55). The combination of these factors led to the resurgence of rights-based appeals under the Charter filed by trade unions on behalf of their members (Savage 2007: 192-94). Although many appeals by the labour movement to the Supreme Court were unsuccessful in the late 1980s, the judicial tide has turned and, by the late 1990s, the Court expanded the repertoire of labour rights that were constitutionally protected.

This paper seeks to analyze the effects of the construction of workers' rights as human rights as it relates to establishing and cultivating rank-and-file workers' capacities and establishing militant, grassroots unions built upon an active and broad-based membership. Building on David Camfield's (2008) typology of trade unions, it further attempts to contextualize what type of unions are most likely to construct labour rights as human rights and what this means for rank-and-file mobilization. It also explores broader causal relations between rights-discourse and union democracy. In so doing, it makes no normative assertions as to whether or not labour rights should be constructed as human rights. There has already been considerable discussion on this point, and each side of the debate had established its position. This paper does, however, accept that fact that - for better or for worse - the union movement has begun to embrace that their rights are in fact human rights and deserving of increased protection. This position has been most forcefully advocated in Canada by the National Union of Public and General Employees (NUPGE), the United Food and Commercial Workers (UFCW), the Canadian Teachers' Federation (CTF) and the Canadian Police Association (CPA), while a number of other unions have made similar rights-based claims and relied on the Canadian Charter of Rights and Freedoms in various cases heard before the Supreme Court in recent years (CPA 2008; Health Services and Support-Facilities Subsector Bargaining Association v. British Columbia [2007] SCC 27).

Utilizing the case study of the Hospital Employees' Union (HEU) struggle against Bill 29, the Health and Social Services Delivery Act, which consisted of a legal strike, followed by an illegal strike which was quickly extinguished by the union's leadership, and culminated in a successful legal challenge under the Charter of Rights and Freedoms, this paper suggests that a reliance on the construction of labour rights as human rights and the corresponding judicial strategy prevents the development of a far more radical, grassroots social movement unionism and instead facilitates the proliferation of more hierarchical, elite dominated forms of trade unionism (mobilization, social and business unionism). Thus, constructing labour rights as human rights offers a cautionary tale for unions, union leaders, and especially for rank-and-file unionists contemplating such an approach. It 
is important for those considering such a strategy to first consider the type of union they desire, and then determine if embracing a rights-based strategy will facilitate or frustrate that process. For those rank-and-file unionists committed to maintaining or establishing some formation of social movement unionism, a rights-based strategy is problematic.

\section{Constructing Labour Rights as Human Rights}

The labour movement's embrace of rights-discourse has garnered significant attention in the academic literature amongst scholars both in favour of this construction (Compa 2000, 2008; Gross 1999, 2003; Swepston 2003; Fudge 2006; Adams 2006) as well as from scholars either hesitant of or fully opposed to this strategy (Mandel 1994: see esp. ch. 5; Brody 2001; Lichtenstein 2003; McCartin 2005; and Savage 2008). The debate between the two has often consisted of competing normative claims as to whether or not labour rights should be constructed as human rights. This is especially true of those who advocate for labour rights to be actualized as human rights. Roy Adams, for example, asserts that 'human beings [must] never be treated as means, but always as ends' and continues that 'for this imperative to be fulfilled the worker must not be treated as a commodity but instead as a human being with an inalienable right to dignified treatment' (Adams 2006: 15). In similar vein, Lance Compa puts forward the argument that 'so long as worker organizing, collective bargaining, and the right to strike are seen only as economic disputes involving the exercise of power in pursuit of higher wages for employees or higher profits for employers, change is unlikely. Reformulating these issues as human rights concerns can begin a process of change' (Compa 2000: 17). Such an approach asserts that the traditional activities of the labour movement - organizing, bargaining, and striking - are not simply activities, but instead are activities deserving of being elevated to human rights. In order to see these activities being elevated from statutory rights to human rights, these scholars rely on the inclusion of the rights to organize, bargaining, and strike in various domestic and international human rights documents (Adams 2008).

The suggestion that labour rights are - or should be - human rights has by no means achieved a hegemonic position within the academic community. Indeed, the very fact that labour rights are human rights is a contested issue. The suggestion that labour rights are human rights is not simply a position advocated by those who have class interests that run counter to those of the labour movement. To be sure, even the International Finance Corporation - the lending arm of the World Bank - publicly maintains that the standard it places on potential loan applicants is that they 'will not discourage workers from organizing and bargaining collectively' (quoted in Adams 2008: 55). The critics of Adams, Compa and others are primarily schooled in the critical legal theory or neoMarxist tradition and provide various normative claims of why it is problematic to construct labour rights as human rights and make further empirical claims of the shortcomings of such a construction. Larry Savage, for example, asserts that constructing labour rights as human rights is problematic because it threatens to undermine class-based responses to neoliberal globalization, downplays the material dimension of workers' collective action, and wrongly assumes that power flows from rights (Savage 2008), while David Brody maintains that such an approach posits a false equality between employer and employee rights and fails to recognize that the legal system - the supposed protector of 
labour's human rights - is not favourable to the collective rights of workers (Brody 2001). In short, the critics of constructing labour rights as human rights maintain that, at best, there are more drawbacks than benefits to this construction, and in some cases are totally dismissive of the value of constructing labour rights as human rights.

Despite a wealth of literature that is critical of constructing labour rights as human rights and the accompanying judicialized strategy required to achieve this, the discussion of the effects of such a strategy on the capacity building and mobilization of the labour movement's grassroots, rank-andfile members has been downplayed. Consequently, this essay seeks to fill the void and analyze in considerable detail the long-term effects of rights-based strategy on rank-and-file activism. Although some discussion of the effects of rights-based strategy on rank-and-file democracy has occurred, it has been done largely in passing and with evidence that is non-existent or, at best, anecdotal. For example, Joseph McCartin, in contrasting the rise of pre-war unionism based on industrial democracy and contemporary unionism based on rights-discourse, maintains that '...the [pre-war] demand for industrial democracy helped counter the tendency of unions to follow the "iron law of oligarchy..." adding that 'it is [now] difficult to imagine how rights talk can foster this democratic spirit' (McCartin 2005: 64). Viewed in this light, a union renewal strategy based upon constructing labour rights as human rights privileges a bureaucratic form of unionism, thus shifting the emphasis from democratic rank-and-file activism to top-down leader-driven unionism. As a result, it is suggested that unions will succumb to the iron law of oligarchy by relying too heavily on rightsbased strategy. ${ }^{1}$

Similarly, in a cautioning account of the effects of the rise of rights discourse within the labour movement, Nelson Lichtenstein argues that 'the spread of employee rights has suffered through its necessary dependence upon professional, governmental expertise' (Lichtenstein 2003: 71). For labour rights to be actualized, rank-and-file workers are forced to rely on union bureaucrats - especially labour lawyers - as opposed to their own active participation. 'Rights consciousness', he continues, '...transfers authority into the hands of another body...to sort out the various claims and strike the approximate balance' (Lichtenstein 2003: 71). While rights-discourse may lead to meaningful ends for rank-and-file workers, the means used to achieve those ends do little to foster a sense of activism amongst workers or to facilitate their capacity building. Lichtenstein aptly concludes that 'justice is served, but not always democratic participation' (2003: 71).

While McCartin and Lichenstein draw important conclusions regarding the effects of constructing labour rights as human rights on democratic rank-and-file participation, they do so only in passing as part of a broader normative argument regarding the limitations associated with rights discourse. Furthermore, they cite no evidence of labour rights campaigns adversely affecting rank-and-file activism and instead present broad generalizations of what they expect to happen under such a construction. While there is considerable merit to their conclusions, they are weakened by sole presence of normative assertions and the absence of empirical evidence. However, the use of both a typology of trade unionism and a concrete case study of a labour-backed, rights-based campaign will strengthen the claim that constructing labour rights as human rights prevents the development of a form a more radical, grassroots, rank-and-file led social movement unionism and instead facilitates the proliferation of more hierarchical, elite dominated forms of trade unionism. 


\section{Developing a Typology of the Labour Movement}

While the labour movement is often viewed as a solidaristic and unified entity, there are various divisions within the broader labour. Unions can be described using various typologies: international unions vs. national unions, public sector union vs. private sector unions, or traditional craft-based unions vs. broader 'general' unions. Another distinction between trade unions relates to what they do and how they go about doing it. David Camfield's overview of trade unionism in Canada conceptualizes four distinct types of trade unionism: business unionism, social unionism, mobilization unionism or social movement unionism (2008: 70-71). While all unions engage in collective bargaining with employers, the way in which the union engages with the rank-and-file, and vice versa, varies considerably. Business unionism '... assumes that unions should be run from the top down by small numbers of officials and staff rather than democratically by an active membership', while social unionism, despite being more critical of neo-liberalism than business unionism, is '... wary of greater militancy or democratic membership control' (Camfield 2008: 70). Although the third type of unionism, mobilization unionism, is willing to use more militant means to defend workers' rights, '...it encourages member involvement but does not challenge the running of unions primarily by staff and top officials' (Camfield 2008: 70). The final type of unionism, social movement unionism, 'puts democratic control of the unions by an active membership at the heart of its approach...' and 'is anti-bureaucratic; that is, it seeks to undermine the dependence of most members on the activity and knowledge of a small number of leaders (usually union officials) by developing members' capacities' (Camfield 2008: 71). ${ }^{2}$ This final type of unionism is the least common, whereas social unionism is the most common type of unionism in Canada.

Camfield's typology is useful in analyzing the effects of rights-discourse on unionism because it illustrates both what kind of unions are more likely to rely on constructing labour rights as human rights and what type of unionism is likely to be created as a result of an increased use of rights-based arguments. Conversely, it also illustrates what types of unions are likely to resist relying on rightsbased arguments and gives some indications as to why. A rights-based strategy inherently involves deference to the legal system, which privileges labour lawyers who argue the case and leaves the final decisions to be made by judges. At the same time, it limits the potential of building the capacity of rank-and-file activists. As Derek Fudge, a strong proponent of constructing labour rights as human rights argues 'we need a coordinated national strategy within the Canadian labour movement to use the judicial system to advance workers' rights in Canada, including joint legal research, communications strategies and financial support on the key cases' (Fudge 2006: 83).

A strategy that utilizes the courtroom as the main battleground struggles to engage the grassroots in any meaningful way, even if it is successful in advancing rights in the end. To be sure, there are no picket captains, no strike mobilization committees, or no shop stewards needed in a

courtroom. Furthermore, rank-and-file members need not even be present. This type of elite-driven strategy suggests that it will not be readily employed by social movement unions, as it fails to challenge the privileged position enjoyed by union staff and elected officials. However, business unionism, social unionism and mobilization, which all accept the running of unions by a hierarchy 
through bureaucratic means are more likely to employ a rights-based strategy as it is consistent with their view of how unions ought to be run.

\section{Theorizing the Hospital Employees' Union}

Founded in 1944, the HEU began as a single bargaining unit at the Vancouver General Hospital and eventually grew into British Columbia's largest health care union, representing over 43,000 members in the province. The HEU describes itself as being 'a strong, democratic, socially conscious union and a passionate defender of public health care in Canada' (http://www.heu.org/about_heu/). The union's rich history helps to place it within Camfield's typology as an example of mobilization unionism, as the past actions as well as its actions during the campaign against Bill 29 illustrate that while the $\mathrm{HEU}$ is critical of neo-liberalism and 'encourages member involvement' in its often militant campaigns, it 'does not challenge the running of unions primarily by staff and top officials' (Camfield 2008: 70).

The HEU has, in the past, engaged in inter-union disputes with the overarching labour federations such as the Canadian Labour Congress (CLC) and the British Columbia Federation of Labour (BC Fed). Following allegations of vote-rigging by the opponents of an HEU secretarybusiness manager during his election for the Canadian Union of Public Employees (CUPE) presidency and an organizing drive by CUPE in acute-care hospitals (traditionally reserved for HEU organizing), the HEU voted to leave CUPE (which it was a founding member of in 1963). This decision in turn led to HEU members being expelled from the CLC, BC Fed, and local labour councils (Isitt and Moroz 2007: 96). Although the HEU eventually returned to CUPE as a 'fully autonomous union with control over name, constitution and structure' and was readmitted to the CLC and BC Fed, it gained the reputation of 'a bastion of militant, independent unionism, a black sheep [that] demonstrated a willingness to strike - in 1992 and again in 1998 - against 'labor's' NDP government' (Isitt and Moroz 2007: 95).

While the actions of the HEU's fight against the right-wing Liberal government and its desires to privatize health services illustrates the union's strong stance against neo-liberalism, the union should be seen as an example of mobilization unionism. Indeed, there are many examples of the HEU encouraging member involvement but failing to challenge the running of unions primarily by staff and top officials. To be sure, former HEU president Fred Muzin (who led the union from 1993 to 2008) suggests that the union's militant tradition comes not from the members, but rather from '... leaders who have been very forward thinking...very progressive' (Muzin, cited in Isitt and Moroz 2007: 96). Muzin went on to note that the membership '...keeps its leaders very accountable. They don't give us an easy rise on anything'. However, this suggests that the locus of decision making is in the top echelons of the union's leadership, not necessarily with the rank-and-file membership, as would be the case with social movement unionism.

Perhaps the clearest example of the HEU's sense of mobilization unionism is evident in Muzin's defense for calling off the massive province-wide general strike that was planned for Monday, 3 May 2004. While the specifics of the end to the strike will be discussed later in the paper, it is worth noting briefly how the HEU leadership's ending of the strike is evidence of their belief in 
mobilization unionism. HEU President Fred Muzin defended the union's actions, arguing that while 'Monday [3 May] would have been a party...Tuesday [4 May] would have been a massive hangover. That's the challenge of leadership. Having to make really tough unpopular decisions' (cited in Isitt and Moroz 2007: 104). A union employing social movement unionism would be critical of the leaders making decisions, and would have instead allowed the union's rank-and-file to determine the best course of action. While Muzin's actions may have been necessary for the union's continued institutional existence (a lengthy illegal strike would have likely led to fines, jail sentences for leaders, and perhaps even decertification) and are rather similar to previous examples of aborted general strikes (Operation Solidarity in B.C. in 1983 and the Days of Action in Ontario in the late 1990s), they illustrate the union's acceptance of mobilization unionism.

\section{The Hospital Employees' Union Fight Back Against Bill 29}

The use of a case study is particularly useful in illustrating how a rights-based strategy, even one that leads to significant advances in workers rights, limits the capacity building of rank-and-file members, fails to fully engage grassroots activists, and fails to challenge hierarchical power relations within unions. As such, a case study, such as the Hospital Employees' Union (HEU) challenge to the British Columbia government's Bill 29, provides a concrete example of how constructing labour rights as human rights frustrates the creation or continuation of social movement unionism, thus leading to the continued prevalence of business, social, and mobilization unionism.

As part of the British Columbia government's broader strategy of accelerating the process of neo-liberalism, they passed into law Bill 29, the Health and Social Services Delivery Improvement Act, which, among other things allowed for extensive privatization and the elimination of services without consultation (leading to the loss of approximately 8000 unionized jobs); stripped hardfought anti-contracting out provisions from collective agreements; greatly restricted successor and bumping rights; eliminated labour forces adjustment/re-training programs; and made it illegal to even discuss alternatives to privatization with employers (Lancaster House 2007). The vast majority of employees ( $85 \%)$ affected by this bill were women, a considerable majority $(57 \%)$ were over the age of 45, and a significant portion (30\%) were born outside of Canada (cited in Camfield 2006: 15). In short, Bill 29 affected predominantly older women, many of whom were black. By analyzing the fight back campaign against the provisions of Bill 29, which resulted in widely supported strike by HEU members, one which was eventually ended with a concessionary settlement and the cancellation of a province-wide strike set at the behest of union leadership, illustrates the effects of constructing labour rights as human rights on rank-and-file activism.

Instead of going through the with the planned province-wide strike, one which by all accounts was widely supported by many of the provinces public and private sectors and their community allies, the union's leadership decided instead to launch of a rights-based Charter challenge against the impugned legislation. While this legal challenge eventually determined that the Charter is sufficiently broad enough to provide protection to the procedure of collective bargaining, thus awarding unions the constitutional right to bargain collectively, the effects of this ruling on grassroots militancy, rank-and-file activism and capacity building cannot be understated. Indeed, 
many HEU members were left with the feeling that they were 'screwed by our own leaders' (Harnett, Ward and Bula 2004: A1).

While the strike began in April 2004, the affected unions (notably the HEU, of which 90\% of the province's health support workers belonged to) began to mobilize shortly after the unannounced passage of Bill 29 in the middle of the night during a special weekend sitting of the legislature on 28 January 2002. There were a number of local protests and demonstrations against the bill during 2002, including a notable one in November in which HEU activists blockaded a truck carrying laundry that was contracted out, leading to the arrest of three members of the union's political executive (see for example Harrison 2002; Cariou 2002; and Culbert 2002). The HEU then held a fight-back conference in early 2003 to promote an anti-privatization strategy and encouraged participants to mobilize their co-workers for action against the bill. Curiously, however, a tentative agreement on a new contract between the HEU and the government was announced shortly thereafter, catching many members off-guard and prompting one staff member to wonder 'Where did this come from? A week and a half ago I thought we were gonna fight to the death' (cited in Camfield 2006: 19). The concessionary agreement was rejected by $57 \%$ of the membership, thus forcing a conflict between the union and government.

Although the HEU's political executive continued to negotiate with the government in an attempt to secure a better deal that the membership would accept, the union held a strike vote to back up their demands for a better contract with the threat of a potential work stoppage. The strike vote, held in March 2004, was backed by over 89\% of the union's membership (Camfield 2006: 22). Under British Columbia's labour law, the union served the 72-hours notice of a strike action on 14 April and picket lines were first erected on 25 April. As David Camfield notes of the workers' militancy and determination in launching the job action: 'as soon as picket lines went up it was obvious that hospital workers who had endured intense stress and anxiety since the passage of Bill 29 were united and committed to the strike' (2006: 24).

The HEU strike, and most strikes in general, are examples of grassroots militancy which can have positive effects in building the capacities of rank-and-file members. The decision to strike is a democratic one made by the workers, and the strike's only hope of being successful is reliant upon rank-and-file support for the strike, most notably in terms of walking the picket line. For many workers, this has the potential to be a powerful experience in terms of making democratic decisions over the conditions of work, bonding with fellow union members through solidaristic action, providing space for active resistance, and illustrating the power of collective action. Furthermore, a successful strike also opens up room for rank-and-file activism in the form of strike preparedness committees, strike action committees, solidarity building with allied community groups, and picket captains. If executed in a bottom-up democratic fashion, a well-run strike can be indicative of social movement unionism, especially if the strike opens up space for developing members' capacities, decision making is left with the rank-and-file, community alliances are forged, and presents a forceful challenge to neo-liberalism.

The BC government acted swiftly - and with considerable force - in order to end the HEU's legal strike. On 29 April, the government passed Bill 37, which not only included back-to-work legislation, but also terms for a unilaterally imposed concessionary agreement that included virtually all of the government's original concessionary demands (Camfield 2006: 24). Despite the 
government's draconian legislation, the HEU's leadership - supported by the large outpouring of rank-and-file activism in the first days of the strike - decided to keep the picket lines up in defiance of the law. While the strike continued on the ground and other unions began to strike in solidarity with HEU (notably CUPE, members of the BC Teachers Federation, and some private sector unions), the union's political executive continued to bargain with the government behind closed doors - without the blessing of the striking membership - in an attempt to both end the strike and gain a modestly better collective agreement that the one unilaterally imposed under Bill 37.

Over the course of the weekend (May 1 and May 2), May Day rallies grew in size, but the British Columbia Federation of Labour (BC Fed), who was involved in the backroom contract negotiations, exemplified its social unionism approach of being wary of democratic control of the union. For example, the BC Fed refused to re-route is pre-planned May Day march to St. Paul's Hospital in Vancouver, an obvious site of protest considering the nature of Bill 29, despite the fact that over 4000 activists were participating in the normally small annual march. Furthermore, 'verbal sparring' occurred between rank-and-file activists calling for a general strike and the BCFL leadership, who sought to 'regain control of the rally' (Camfield 2006: 30). As one activist noted of the union leadership's presence at the rally and insistence upon controlling it, 'I knew...that we (rank-and-file activists calling for a general strike) were in serious trouble' (quoted in Camfield 2006: 31). Indeed, by Sunday 2 May, the day before a planned shut-down of the broader public sector and many private sector workplaces, a deal was struck between the union's executive, the BC Fed, and the government-employer. The concessionary settlement, which the HEU Political Executive voted to accept 13-7, also saw the union agreeing to 'direct its members back to work forthwith' (quoted in Camfield 2006: 31).

\section{Analyzing the Cancellation of the General Strike}

The signing of a major collective agreement and memorandum to end a widely-supported general strike, even one in defiance of the law, is a telling example of the top-down bureaucratic control of business, social, and mobilization unionism (as previously mentioned the HEU, is best seen as an example of mobilization unionism). Indeed, the signing of a closed-door agreement by the union's leadership is consistent with a typology that is weary of increased democratic control by rank-and-file members and promotes the running of union's by staff and top officials. By ending the strike, the union's leadership not only eliminated space for rank-and-file members to develop their capacities on the picket line, it also denied them the opportunity to have their voices heard in their own union and have meaningful input on obviously important issues. This fact was not lost on many rank-and-file activists whose actions and beliefs implicitly (and in some cases explicitly) supported social movement unionism in which decision making would be left largely in their hands. As an HEU staffer asserted, 'people were really, really angry. People had no idea that that was the deal that being contemplated, people were angry that they didn't get to vote on it...', while an executive member of the HEU local at Vancouver's General Hospital maintained that 'I don't even know how [the union's leadership] could call it a victory for working people. We have been sold out' (quoted in Camfield 2006: 32). 
The HEU's sense of mobilization unionism was particularly evident in regards to the leadership calling off the planned general strike and unilaterally reaching an agreement with the government to return its membership back-to-work. Of the settlement, which retained a $15 \%$ wage rollback (but no longer made it retroactive), limited further contracting out to 600 full-time equivalents, and provided an additional \$25 million in settlement pay, Muzin argued that despite the willingness of the union's membership - and much of the BC labour movement for that matter - to engage in a general strike in defiance of the law, 'we felt it was the maximum that we were going to be able to achieve at that time and place' and that 'there was a great groundswell to the point where people forgot that the genesis was a bargaining dispute' (cited in Isitt and Moroz 2007: 104).

What began as, and could have been, a major shift toward social movement unionism, regressed into a situation in which rank-and-file decision making was rejected in favour of bureaucratized, top-down, decision making. Eric Tucker notes that 'as momentum toward a widening sympathy strike was building, top labour officials...quietly negotiated a memorandum that slightly modified the terms of the back-to-work legislation, and the strike was called off. The memorandum was not put to a vote among the affected workers' (2008: 155). Indeed, had it not been for the HEU Political Executive's decision to negotiate a backroom agreement and deny the membership the chance to vote on it, a sympathy strike consisting of and led by rank-and-file activists would have facilitated grassroots capacity building and challenged the hierarchical nature of the union's structure.

While the rank-and-file led struggle against Bill 29 may have ended with the concessionary settlement reached in early May 2004, the campaign against the Bill was far from over. What was different in the new phase of struggle, however, were the actors involved in it and the venue in which it was fought. As opposed to the resistance occurring in the streets and being enriched by rank-andfile activism, the second stage of the battle against Bill 29 occurred in the courtroom, with labour lawyers and labour leaders playing the major role. ${ }^{3}$ Further, various International Labour Organization (ILO) accords and the Canadian Charter of Rights and Freedoms were utilized as central tools in the fight back campaign, as opposed to the determination and capacities of the union's grassroots membership. Curiously, arguments regarding Bill 29 at the British Columbia Court of Appeal began on May 3, 2004- the day on which the rank-and-file supported strike activity was set to escalate in the province. This strike, of course, was called off on the same day that legal arguments began in the court room. While this may have been coincidence (and, to be sure, there is no evidence to the contrary), it is possible that a large part of the reason why the union's executive decided to end the strike and impose a collective agreement on the membership was because they knew they would have a second chance to defeat the legislation at the Court of Appeal.

There is, however, some evidence to support the claim that a union's leadership will forego militant direct action in lieu of a legal challenge. Michael Mandel argues that the Charter'provide[s] the union with a quick and politically costless way of appearing not to back down' (1994: 278). By way of example, he asserts that the contrasting response on the part of the Canadian Union of Postal Workers - often seen as the most militant union in Canada - regarding back-to-work legislation passed by the federal government in both 1978 and 1987 illustrates this point. The 1978 back-towork legislation was defied by the rank-and-file and CUPW president Jean-Claude Parrot spent three month in jail as a result of refusing to urge the membership to return to their jobs; the 1987 
legislation was obeyed 'forthwith,' and the union's response to this was simply to challenge the impugned legislation in court, though when all was said and done, this legal challenge was eventually dropped by the union and never actually heard before the courts (Mandel 1994: 273-79).

Viewed in this light, the leadership of the HEU may have made the strategic decision that arguing the case before the provincial Court of Appeal was, to borrow Mandel's words, a quick and politically costless way of appearing not to back down from the government. Whether or not the union executive's intentions were as underhanded as this is not the central point, though the simultaneous occurrence of both the end of the strike and the beginning of the legal arguments at the Court of Appeal are perhaps telling. In any event, the central point is that by relying solely on a legal challenge, as the HEU did after ending the strike in early May, the union not only denied the grassroots membership a voice in determining the union's course of action, it also failed to provide meaningful opportunities for the rank-and-file to develop their own capacities and left both the decision making process and process of struggle to already privileged actors, notably labour lawyers, permanent union staff, and the union's elected leadership.

Two months later, however, the Court of Appeal dismissed the union's appeal, relying on the Court's longstanding precedent that section 2(d) of the Charter did not extend to collective bargaining, arguing that '.. while Bill 29 may affect the appellants' bargaining strength, it does not interfere with the protected aspects of their collective bargaining rights' (Health Services and SupportFacilities Subsector Bargaining Association v. British Columbia [2004] BCCA 377: para 88). Following this ruling, the union had no choice but to seek leave to the Supreme Court of Canada, though there is some likelihood that this was the preferred strategy of the union's leadership from the start. In June 2007, the Supreme Court of Canada overturned the lower courts and its own twenty-year precedent, ruling that freedom of association guaranteed by s section 2(d) of the Charter includes a procedural right to collective bargaining. Relying on a combination of Canadian labour history and the role that collective bargaining played in it, international labour conventions that affirm the protection and desirability of collective bargaining, and an expanded notion of Charter values and freedom of association rights, the Court reasoned that the right to bargain collectively, is part of the Charter's larger goal of promoting 'dignity, personal autonomy, equality and democracy' that is inherent within the country's constitution (Health Services and Support-Facilities Subsector Bargaining Association v. British Columbia [2007] 2 S.C.R. 391, 2007 SCC 27: para 86).

Needless to say, this decision was warmly received by many trade union officials and union leaders across Canada. Paul Cavalluzzo, a Toronto-based labour lawyer representing the United Food and Commercial Workers (UFCW), an intervener in the case, remarked that 'it's a magnificent victory for workers in Canada', while Judy Darcy, secretary-business manager for the Hospital Employees Union, added that 'people....jump for joy, they cry, they shriek...' when hearing about the decision (Tyler, B1; Brethour and Drake, S1). The rank-and-file, however, on whom a collective agreement was unilaterally imposed, whose democratic decision making was impeded, and whose capacity building was denied, were less optimistic than the union officialdom. Upon hearing the verdict in Health Services Sheila Niehaus, a care-aide who was laid off three times under Bill 29's provisions, remarked 'I'm only on cloud 83/4...let's put it that way' (Brethour and Drake, S1). 
The effects of this ruling have been interpreted in a number of different ways. Eric Tucker argues that the Court's decision forced the government to re-negotiate with the HEU, leading to a tentative settlement that provided a meaningful remedy (2008: 174). Charles Smith, despite noting some limitations to the Court's ruling, encourages '.. the labour movement... [to] rightfully see this as a victory. The court has now affirmed that workers have certain constitutionally protected rights that governments cannot simply legislate away' (Smith 2007: 31). More critically, Larry Savage has concluded, 'far from revolutionary, the Court's decision in Health Services simply shields public sector unions from the worst excesses of neo-liberalism by confirming the public policy environment of the post-war compromise' (Savage 2007: 180). Despite these important contributions discussing the implications of the Court's decision, the purpose of this paper was not to assess whether or not the ends - in this case the Court's decision - were good or bad for workers, but rather, to assess the means used by the HEU. In other words, the purpose has been to examine the implications of union's relying on the legal system to make these pivotal decisions for them as opposed to allowing rank-and-file driven activism to play the decisive role in forcing the hands of neo-liberal governments or hostile employers. Indeed, as unions are increasingly reliant upon a legalistic rightsbased strategy that uses the judicial system to enforce the statutory rights of workers, it is necessary to examine the effects of this strategy on rank-and-file mobilization. David McNally notes that studies of mass movements tend to place 'the emphasis... on the object (reform) but not on the process (struggle) that produces it' (2006: 367). This essay has attempted to re-insert the process or the struggle as its central unit of analysis.

\section{The Aftermath of Bill 29 Fightback Campaign}

Despite the unilateral end to the planned general strike, there appears to have been little fallout in the union. While some rank-and-file members felt 'betrayed', 'angry', and that 'we could have won more had we stayed out', many rank-and-file members were convinced that the leadership's decision to settle and end the strike was the best one (Annis 2004). The reflections of 'Cheryl,' a cardiology technician at Vancouver General Hospital are perhaps telling. She noted that she 'was angry at the union when the news [of the settlement] broke. But I attended the information meeting later that day and started to think it was the best decision' (cited in Annis 2004). This sentiment seems to be commonplace, as the union's leadership seems to have convinced many of those critical of the decision to end the strike that it was in the union's best interest. To be sure, there were no major changes to the union's senior leadership at the 2004 or 2006 biennial conferences.

Although Secretary-Business Manager Chris Allnutt resigned from his (unelected) position in the union in August 2003, President Muzin was re-elected in October 2004 (and again in 2006), as was Financial-Secretary Mary Laplante, who did not seek re-election in 2006 (Cariou 2004). While no changes to the union's leadership were made, some fifty delegates (of the 510 total delegates) did speak against the HEU's handling of the strike. For its part the HEU did release a bulletin at the convention stating that 'a predominant theme, during [the discussion at the convention] was the union's failure to communicate to the rank and file the shifting circumstances leading to the 2 May 
memorandum' (cited in Cariou 2004). While the union admitted to a problematic process, it saw no problem with the final results. This provides further evidence of the HEU's sense of mobilization unionism.

\section{Conclusion}

By employing the case study of the HEU's fight back campaign against Bill 29 in British Columbia, this essay has explored many of the implications of moving away from a rank-and-file driven, capacity building militant approach to a legalistic, bureaucratic and, in the case study employed in this analysis, a legalistic, hierarchical and rights-based approach. Relying on David Camfield's typology of unionism, the move toward a legalistic, bureaucratic and potentially (though not always) anti-democratic rights-based approach is likely to run contrary to social movement unionism's goal of 'put[ting] democratic control of the unions by an active membership...' and most certainly conflicts with social movement unionism's anti-bureaucratic tendencies that seek '...to undermine the dependence of most members on the activity and knowledge of a small number of leaders (usually union officials) by developing members' capacities' (2008: 71). In the case of the HEU's fight back campaign, it appears that the BC labour movement's political executive and leadership made a conscious decision to forego an illegal, and potentially lengthy, province-wide sympathy strike and decided instead to use a rights-based strategy. By taking the decision making capacity out of the hands of rank-and-file members and failing to build the grassroots' capacities, the top-down, bureaucratic and elitist modes of business, social, and mobilization unionism were reinforced. In other words, these three types of unions are the ones most likely to employ a rightsbased strategy as a central feature of any fight back campaign as it is consistent with their understanding of how a union should be run, who should exert power, and where this power should be exerted.

Of course, this paper only employs a single case study to examine the relationship between labour rights and union democracy. The use of a single case study allows for a detailed examination of a historical event - such as the HEU's fight-back against Bill 29 - to “...develop and test historical explanations generalizable to other events' (George and Bennett 2005: 5). As an examination of this causal relationship had yet to be explored in the literature, a single-case study serves as a useful starting point to illuminate what could be an important relationship. To be sure, however, further examination of this relationship utilizing a multiplicity of cases is necessary. Nonetheless, the single case study of the HEU has illuminated a previously unexplored field and has identified a potentially important causal relationship. While it is too early to generalize this relationship, the typology and methodology utilized here can certainly be transplanted to future scholarship in the area.

The important question, then, is to ask what we can draw from this case study. While this paper has identified a potentially important causal relationship, as well as the need for future research broader in scope, the use of this case study also highlights many important relationships in and of itself. Firstly, it illustrates an important lesson for those unionists seeking to build social movement unionism. It suggests that a rights-based strategy appears ill-suited to foster the bottom-up, anti- 
hierarchical strategies that can provide a meaningful challenge to more traditional forms of unionism. Without a chance for the rank-and-file membership to engage in militant activities, whether in the form of conventional strikes or non-conventional protests, capacities that must be developed in order to challenge the activities and knowledge of the union officialdom are simply not built. Utilizing Camfield's typology, this paper also identifies which unions are less likely to utilize a right-based approach. This paper suggests that we can expect unions and unionists adhering to a strategy of social movement unionism to be more hesitant of employing a rights-based strategy as such a strategy fails to challenge the internal power structure of the labour movement.

This paper also contributes to the literature on union renewal, particularly in an era of neoliberalism when the rights of workers are being routinely violated by governments. In terms of looking forward to a broader strategy of union renewal, this paper indicates that emphasis must be placed on social movement unionism. If new political projects designed to increase the strength and influence of organized labour are to be sustained, it will be necessary to facilitate the growth of union movement's grassroots membership, develop their capacities to run a militant local, and ensure that meaningful democracy is present within the union's overarching structure (Gindin and Stanford 2003; Albo and Crow 2008). The only type of unionism capable of achieving this is social movement unionism. It is also the only type of unionism capable of sustaining a meaningful challenge to the neo-liberal status quo.

This paper has also highlighted a number of other important interrelated causal relationships. Firstly, as previously mentioned, it suggests that the type of union will inform the union's strategy in regards to rights-based arguments. Secondly, in-turn, the utilization of a rightsbased approach by business, social, and mobilization unionism has the potential to impede the development of a militant rank-and-file base. If labour leaders, lawyers, and judges can make improvements for workers, then there is less of a need for workers to take matters into their own hands and make these improvements through direct action and build the capacities required to do this. Of course, future case studies are likely to illuminate these relationships, leading to a situation in which they can be more generalizable.

This is not to suggest that all rights-based strategies are anti-democratic or serve only to frustrate a capacity building exercise for rank-and-file activists. As the civil rights movement in the United States has illustrated, a campaign centered on human rights can galvanize grassroots activists and serve as a turning point in a broader struggle. However, by turning to the courts too early and quelling grassroots activism (as was the case with the decision to end the strike), the potential of a rights-based campaign to foster democratic participation is greatly limited. The labour movement can use rights-discourse to its advantage, but should utilize it in the workplace, the streets, on the picket lines and in the community before turning to the courts. While the courts may play an important role in rights enforcement, it should be a last resort for unions and only utilized after all avenues for rank-and-file activism have been exhausted.

Indeed, while the temptation of a rights-based strategy may seem like a panacea to a labour movement that is confronting significant challenges, especially following the 'victory' in Health Services, one must be cautious of the potential downfalls of quelling militant grassroots activism in lieu of a legal challenge, or, even worse, relying solely on a rights-based approach. As Lichtenstein succinctly argues, 'to flourish again, trade unionism does require civil rights and human rights and 
their vigorous enforcement in every global workplace...but this is not enough' (2003: 71). Ideally, unions must seek to mobilize their grassroots membership, build the capacities of the rank-and-file, and encourage militant action. The time will come when unions will no longer need to do these things for the membership (suggesting a top-down approach) as much as rank-and-file members will began to demand them (a bottom-up approach). While constructing labour rights as human rights may be tempting for many within the labour movement, union activists supportive of a social movement unionism must recognize the downside of this strategy and see it, at best, as one of many strategies in defending their rights. However, to avoid being confined to hierarchical and bureaucratic unionism, rank-and-file activists should ensure that all other possible avenues of resistance are exhausted before turning to the courts as a venue for their struggle.

\section{NOTES}

${ }^{1}$ The Iron Law of Oligarchy, developed in 1911 by German sociologist Robert Michels, argues that all organizations will develop in oligarchies (rule by the elite), regardless of how democratic they were originally structured. The leadership within an oligarchical organization will consolidate their own interests and immobilize the masses. See Robert Michels, Political Parties: A Sociological Study of the Oligarchical Tendencies of Modern Democracy, trans. Eden Paul and Cedar Paul, New York: Free Press, 1915. For an analysis of union bureaucracies, see Mark Leier, Red Flags and Red Tape: The Making of a Labour Bureaucracy, Toronto: University of Toronto Press, 1995.

${ }^{2}$ Greg Albo and Dan Crow also have developed a typology of unionism that includes four types of union organizations: business unionism, social partnership, corporatist, and social movement unionism. Social movement unionism, for Albo and Crow, is oriented to building the capacities of union members to challenge hierarchical relations in the workplace beyond just wage bargaining' and 'attempts to organize the working class as a whole in the struggle for democratization in social justice'. See Greg Albo and Dan Crow, 'Under Pressure: The Impasses of the North American Labour Movements', in Politics in North America: Redefining Continental Relations, eds. Y. AbuLaban, R. Jhappan and F. Rocher, Peterborough: Broadview, 2008. I employ Camfield's typology for its emphasis on internal union structures.

${ }^{3}$ Admittedly the union launched a legal challenge to Bill 29 shortly after its passage in 2003. The original case was dismissed by the British Columbia Supreme Court on September 11, 2003. See The Health Services and Support-Facilities Subsector Bargaining Association et. al v. Her Majesty the Queen et. al. [2003] BCSC 1379. The case was subsequently granted leave to the British Columbia Court of Appeal. See Health Services and Support-Facilities Subsector Bargaining Association v. British Columbia [2004] BCCA 377. The use of the term 'second stage' denotes the legal challenge that began after the cancelled province-wide strike in May 2004. 


\section{REFERENCES}

Adams, R.J. (2006) Labour Left Out: Canada's Failure to Protect and Promote Collective Bargaining as Human Right. Ottawa: Canadian Centre for Policy Alternatives.

Adams, R.J. (2008) 'From Statutory Right to Human Right: The Evolution and Current Status of Collective Bargaining', Just Labour: The Canadian Journal of Work and Society 12: 48-67.

Albo, G. and Crow, D. (2008) 'Under Pressure: The Impasses of the North American Labour Movements', Y. Abu-Laban, R. Jhappan and F. Rocher (eds), Politics in North America: Redefining Continental Relations (pp. 273-294). Peterborough: Broadview.

Annis, Roger (2004) 'Drawing the Lessons of the HEU strike', Seven Oaks: A Magazine of Politics, Culture and Resistance. Available at: http://www.sevenoaksmag.com/features/12_heu.html [Accessed 30 December 2010].

Brethour, P. and Drake, L. (2007) 'Unions Hail Ruling as Tremendous Victory', Globe and Mail (9 June): $S 1$.

Brody, D. (2001) 'Labor Rights as Human Rights: A Reality Check', British Journal of Industrial Relations 39(4): 601-05.

Camfield, D. (2006) 'Neoliberalism and Working-Class Resistance in British Columbia: The Hospital Employees' Union Struggle, 2002-2004', Labour/Le Travail: Journal of Canadian Labour Studies 57: 9-41.

Camfield, D. (2008) 'The Working Class Movement in Canada: An Overview', in M. Smith (ed) Group Politics and Social Movements in Canada (pp. 61-84). Peterborough: Broadview Press.

Canadian Police Association (2008) 'Labour Organizations Call on Prime Minister Harper to Ratify International Human Rights Conventions', 27 November. Available at: http://www.cpaacp.ca/media_communications/read_article_e.asp?ArticleID=111\&reqYear=2008 [Accessed 28 November 2009].

Cariou, K. (2002) 'BC’s Fightback', Canadian Dimension 36(March/April): 8-9.

Cariou, K. (2004) 'Sparks Fly at HEU Convention', People's Voice, 1-15 November. Available at: http://www.peoplesvoice.ca/Pv01 no04.html [Accessed on 30 December 2010].

Compa, L. (2000) Unfair Advantage: Worker's Freedom of Association in the United States Under International Human Rights Standards- A Human Rights Watch Report. Available at: http://www.hrw.org/legacy/ reports/2000/uslabor/ [Accessed on 29 November 2009]. 
Compa, L. (2008) 'Labor's New Opening to International Human Rights Standards', WorkingUSA: The Journal of Labor and Society 11(1): 99-123.

Culbert, L. (2002) 'Union Chiefs Arrested at Blockade: Fraser Valley Hospital Workers Block Trucks Taking Laundry to Calgary', Vancouver Sun, online edition (23 November).

Draper, H. (1977) Karl Marx's Theory of Revolution, v. 1. New York: Monthly Review Press.

Fudge, D. (2006) Collective Bargaining in Canada: Human Right or Canadian Illusion? $2^{\text {nd }}$ edition. Halifax: Fernwood Publishing.

George, A.L. and Bennett. A. (2005) Case Studies and Theory Development in the Social Sciences. Cambridge: The MIT Press.

Gindin, Sam and Jim Stanford (2003) 'Canadian Labour and the Political Economy of Transformation', in W. Clement and L. Vosko (eds.) Changing Canada: Political Economy as Transformation (pp. 422-442). Montréal and Kingston: McGill-Queen's University Press.

Gross, J.A. (1999) 'A Human Rights Perspective on U.S. Labour Law Relations Law: A Violation of the Right of Freedom of Association', Employee Rights and Employment Policy Journal 3(1): $1-38$.

Gross, J.A. (2003) 'A Long Overdue Beginning: The Promotion and Protection of Worker's Rights as Human Rights, in J. Gross (ed). Workers' Rights as Human Rights (pp. 1-22). Ithaca: Cornell University Press.

Harrison, D. (2002) 'BC’s Protracted Class War', Canadian Dimension 36(2): 12-13.

Harnett, C.E., Ward, D. and Bula, F. (2001) 'Health Care Workers Feel "Sold Out" by Their Union Leaders', Vancouver Sun (4 May): A1.

Hein, G. (2001) 'Interest Group Litigation and Canadian Democracy', in P. Howe and P.H. Russell Judicial Power and Canadian Democracy (pp. 414-55). Montréal and Kingston: McGillQueen's University Press.

Hospital Employees Union. Available at: http://www.heu.org/ [accessed 30 December 2010].

Issit, B. and Moroz, M. (2007) 'The Hospital Employees' Union Strike and the Privatization of Medicare in British Columbia, Canada', International Labor and Working-Class History 71: 91-111. 
Lancaster House, Supreme Court Watch - Recent Decisions - Health Services and Support Facilities Subsector Bargaining Assn. v. British Columbia (2007) Available at: http://www.lancasterhouse.com/supreme/recent_health.asp [Accessed on 3 December 2009].

Leier, M. (1995) Red Flags and Red Tape: The Making of a Labour Bureaucracy. Toronto: University of Toronto Press.

Lichtenstein, N. (2003) 'The Rights Revolution', New Labor Forum 12(1): 61-73.

Mandel, M. (1994) The Charter of Rights and the Legalization of Politics, Revised Edition. Toronto: Thompson Educational Publishing, Inc.

McCartin, J. (2005) 'Democratizing the Demand for Workers' Rights: Toward a Re-Framing of Labor's Argument', Dissent (Winter): 61-71.

McNally, D. (2006) Another World is Possible: Globalization and Anti-Capitalism, revised and updated edition. Winnipeg: Arbeiter Ring.

Michels, R. (1915) Political Parties: A Sociological Study of the Oligarchical Tendencies of Modern Democracy, trans. E. Paul and C. Paul. New York: Free Press.

National Union of Public and General Employees /United Food and Commercial Workers. Labour Rights. Available at: http://www.labourrights.ca/ [Accessed on 3 December 2009].

Panitch, L. and Swartz, D. (2003) From Consent to Coercion: The Assault on Trade Union Freedoms, $3^{\text {rd }}$ edition. Aurora, Ontario: Garamond Press.

Savage, L. (2008) 'Labour Rights as Human Rights? A Response to Roy Adams', Just Labour: The Canadian Journal of Work and Society 12: 68-75.

Savage, L. (2007) 'Organized Labour and the Canadian Charter of Rights and Freedoms', The Supreme Court Law Review, second series 36: 175-99.

Smith, C. (2007) 'Supreme Court Shifts on Right to Bargain', Relay: A Socialist Review Project 18(July/August): 31.

Swepston, L. (2003) 'Closing the Gap between International Law and U.S. Labour Law', in J. Gross (ed.) Workers' Rights as Human Rights (pp. 53-77). Ithaca: Cornell University Press. 
Tucker, E. (2008) 'The Constitutional Right to Bargain Collectively: The Ironies of Labour History in the Supreme Court of Canada', Labour/Le Travail: Journal of Canadian Labour Studies 61: 151-180.

Tyler, T. (2007) 'Top Court Protects Bargaining', Toronto Star (9 June): B1.

\section{CASE LAW}

(The) Health Services and Support - Facilities Subsector Bargaining Association et. al v. Her Majesty the Queen et. al., (2003) BCSC 1379.

Health Services and Support- Facilities Subsector Bargaining Association v. British Columbia (2004) BCCA 377.

Health Services and Support- Facilities Subsector Bargaining Association v. British Columbia (2007). 2 S.C.R. 391, 2007 SCC 27.

\section{BIOGRAPHICAL NOTE}

BRAD WALCHUK is completing his Ph.D. in Political Science at York University. His dissertation explores the politics of the Ontario Labour Relations Board in the era of neo-liberalism. Brad's work has been published in Just Labour: A Canadian Journal of Work and Society and in Labor Studies Journal. 